\title{
MISUSING THE "NO DUTY" DOCTRINE IN TORT DECISIONS: FOLLOWING THE RESTATEMENT (THIRD) OF TORTS WOULD YIELD BETTER DECISIONS
}

\author{
STEPHEN D. SUGARMAN ${ }^{*}$
}

\begin{abstract}
Focusing on a recent California Supreme Court decision, Verdugo v. Target Corp., the author analyzes the "no duty" doctrine and its improper use in recent tort decisions. He argues that too many US appellate courts are misapplying the "no duty" doctrine by using it in situations in which they are actually deciding whether there has been a breach of the duty of care. The author places recent applications of the "no duty" doctrine in the context of recommendations made by the American Law Institute, and suggests that the case law would benefit if the courts reflected upon the relative roles of judges and juries and followed the guidance of the Restatement (Third) of Torts.
\end{abstract}

\section{TABLE OF CONTENTS}

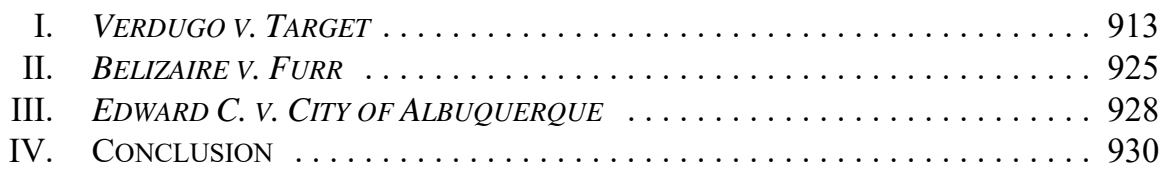

\section{VERDUGO V. TARGET}

On 31 August 2008, Mary Ann Verdugo, then age 49, suffered a sudden and unexpected cardiac arrest while shopping at a Target store in southern California. She collapsed. ${ }^{1}$ A 911 call was made and paramedics arrived a short time after, but not soon enough to save her life. Her mother and brother (who were shopping with her at the time of her death) then filed a tort claim against Target.

Their lawsuit alleged that Target was negligent in not having an automated external defibrillator (AED) available in the store to be used (best by trained personnel) to treat Mary Ann before the paramedics arrived. Plaintiffs claimed that had an AED been available and used, Mary Ann's life would likely have been saved.

The California Supreme Court eventually held in June 2014 that Target has no common law "duty" to have AEDs available for use in its stores. ${ }^{2}$ This holding, I argue, represents an

Roger J Traynor Professor of Law, UC Berkeley Law.

Verdugo v Target Corp, 327 P (3d) 774 (Cal 2014) [Verdugo SC], (Plaintiffs' Complaint) [Verdugo Plaintiffs' Complaint] [on file with the author] (the complaint states that she "lost consciousness without warning and fell backwards onto a metal merchandise rack, slamming her head against it, and suffering cardiac arrest" at 3).

2 Verdugo SC, ibid. Procedurally, the plaintiffs initially filed their case in state court, and Target removed the case to the federal district court which dismissed the complaint. The plaintiffs appealed to the Ninth Circuit which then certified a question to the California Supreme Court which issued the decision under discussion here. See Verdugo v Target Corp, 704 F (3d) 1044 (9th Cir 2012) [Verdugo 9th Cir]. Perhaps unfortunately, the Ninth Circuit's question was cast in "duty" terms: "In what circumstances, if ever, does the common law duty of a commercial property owner to provide emergency first aid to invitees require the availability of an Automated External Defibrillator ("AED") for cases of sudden cardiac arrest?" (ibid at 1045). As an aside, the plaintiffs' lawyers initially claimed not only that Target was liable in tort but also they included several other causes of action which will be ignored here. After the California Supreme Court's decision, the Ninth Circuit affirmed the federal district court's dismissal of the case. 
important misuse of the "no duty" doctrine in torts. ${ }^{3}$ I focus on this particular case both because it was recently decided by the highest court of our largest state and, more importantly, because I hope my point is readily understood in this context. This is, alas, but one of all too many tort decisions these days in which "no duty" is doing work it should not be doing, as I will further illustrate.

Mary Ann was a business invitee of Target, a commercial enterprise that holds its stores open to the public. Under California law ${ }^{4}$ and the Restatement (Third) of Torts ${ }^{5}$ there is no question that they owed her a duty to come to her aid. By contrast, other shoppers in the store owed her no duty because of the longstanding common law rule followed throughout the US that ordinary people have no obligation to come to the aid of strangers. ${ }^{6}$ The justification for this latter "no duty" rule is contested and some find none of the various arguments offered on its behalf persuasive. ${ }^{7}$ Regardless, that is clearly the US law.

But it is now well-understood that the relationship between enterprises and customers on their premises is quite a different matter. Section 40 of the Third Restatement puts it simply: "(a) An actor in a special relationship with another owes the other a duty of reasonable care with regard to risks that arise within the scope of the relationship. (b) Special relationships giving rise to the duty provided in Subsection (a) include ... (3) a business or other possessor of land that holds its premises open to the public with those who are lawfully on the premises." 8

So, when Mary Ann collapsed in the Target store, and assuming it was instantly obvious to Target employees that she was in need of immediate medical attention, had those employees done nothing to summon help by calling 911, that clearly would have been a breach of their duty of due care to their customer. ${ }^{9}$ And had no one else called 911 either, and if it could have been further shown that summoning help via 911 would have saved Mary Ann's life, Target presumably would have been held liable for her death. Of course, that is not what happened, and in this situation it turned out that calling 911 was not enough to save her. Would having an AED on the premises have done so?

For a broad examination of when "no duty" in torts should apply, see Stephen D Sugarman, "Why No Duty?" (2012) 61:2 DePaul L Rev 669.

$4 \quad$ Verdugo SC, supra note 1 at 789. See also Delgado v Trax Bar \& Grill, 113 P (3d) 1159 (Cal 2005). Restatement (Third) of Torts: Liability for Physical and Emotional Harm \& 40 (2012) [Third Restatement]. As discussed later, the Court oddly makes no mention of the Third Restatement and writes as though the Restatement (Second) of Torts (1965) [Second Restatement] is all that exists.

$6 \quad$ Third Restatement, ibid, $\S 37$.

See e.g. Ernest J Weinrib, "The Case for a Duty to Rescue" (1980) 90:2 Yale LJ 247; Saul Levmore, "Waiting for Rescue: An Essay on the Evolution and Incentive Structure of the Law of Affirmative Obligations"(1986) 72:5 Va L Rev 879.

$8 \quad$ Third Restatement, supra note 5, $\S \S 40(a)-(b)$. See also $\S 51$ which describes the duties of land possessors to entrants: (a) is about risks that possessors create to entrants; (b) is about artificial conditions that create risks to entrants; and (c) is about natural conditions that create risks to entrants. None of these would apply to Mary Ann's case. But (d) adds "other risks to entrants on the land when any of the affirmative duties provided in Chapter 7 is applicable." See Reporters' Notes in Third Restatement, ibid (explaining how § 51(d) fits with § 40(b)(3)). Verdugo SC, supra note 1 at 789. 
In the US, the American Heart Association (AHA) is very keen on AEDs and in getting them made widely available. ${ }^{10}$ The American Red Cross is also part of that campaign. Its goal is to have everyone no more than four minutes away from an AED, and it estimates that 50,000 lives a year in the US could potentially be saved as a result. ${ }^{11}$ It turns out that merely having an AED nearby, while potentially very helpful, is not always sufficient. Even if wellmarked in their cases on walls where they are typically displayed, many people do not know what AEDs really are or how to use them, and are fearful or otherwise reluctant to spring into action and try to use one even if they see someone in need. This is unfortunate since AEDs are actually simple to use, typically have easy-to-follow instructions (often spoken to wouldbe users at the press of a button), and can in fact be effectively deployed by those with no experience (including naïve sixth graders according to one study). ${ }^{12}$ So, just like cardiopulmonary resuscitation (CPR), it is better if people are trained in AED use if for no other reason than they are more likely to step up and try to help.

For this reason, the AHA has long been campaigning to get organizations and those in charge of physical spaces both to obtain AEDs and to train their people (typically employees) in how to use them. As an enticement, or at least in hopes of eliminating what might be perceived as a barrier to taking on this responsibility, the AHA has sponsored tort immunity statutes that have been passed (on roughly the same terms) by legislatures in all 50 states of the US. ${ }^{13}$ These statutes basically provide that (1) anyone who in good faith and not for compensation tries to use an AED to help someone in an emergency is immune from tort liability; and (2) entities that acquire AEDs for emergency use are also immune from claims of negligence so long as they have met certain criteria such as regularly maintaining and testing their AEDs, training people in the use of their AEDs, having someone around on the premises who has been so trained, etc. ${ }^{14}$ These statutes, of course, do not require anyone to acquire an AED and make it available for use. This tort immunity offer contained in California law was not a sufficient incentive for Target, at least not in the store where Mary Ann was shopping.

California and other states have mandated that certain actors must acquire AEDs and make them available for use, train employees how to use them, and the like. The main target of these statutes is what California law calls "health studios" (commonly called health clubs or fitness centers). ${ }^{15}$ Target is not one of those. California has also taken action to get AEDs in public buildings and to have public employees trained in their use. ${ }^{16}$ This, of course, does not apply to Target either.

See e.g. American Heart Association, "AED Programs Q \& A" (25 June 2015), online: American Heart Association <www.heart.org/HEARTORG/General/AED-Programs-Q-A_UCM_323111_Article.jsp>; American Heart Association, "Highlights of the 2010 American Heart Association Guidelines for CPR and ECC" (2010), online: American Heart Association<www.heart.org/idc/groups/heart-public/@wcm/ (a)ecc/documents/downloadable/ucm 317350.pdf $>$.

11 American Red Cross, "Learn About Ätomated External Defibrillators" (2016), online: American Red Cross $<$ www.redcross. org/prepare/location/workplace/easy-as-aed $>$.

John W Gundry et al, "Comparison of Naive Sixth-Grade Children with Trained Professionals in the Use of an Automated External Defibrillator," (1999) 100:16 Circulation 1703.

13 Verdugo SC, supra note 1 at 778; AED Brands, "AED State Laws" (2015), online: <www.aedbrands. com/resource-center/choose/aed-state-laws/>.

$14 \quad 3$ CA Civil Code $\S 1714.21$ (West 1999); 2.5 CA Hlth \& S $\S 1797.196$ (West 1999). The AHA has also supported government programs that help fund the acquisition of AEDs, especially by state and local governments.

$15 \quad 103$ CA Hlth \& S, ibid, § 104113 (West 2005).

$16 \quad$ CA Govt tit $2 \S 8455$ (West 2004). 
The state of Oregon has adopted a statute that requires, among other things, that business buildings of at least 50,000 square feet where the public comes to shop (among other things) must have at least one AED on their premises. ${ }^{17}$ Since Target stores appear to average more than 100,000 square feet, ${ }^{18}$ it seems safe to assume that its stores in Oregon comply with this rule. ${ }^{19}$ But since this law was not enacted until $2009,{ }^{20}$ Oregon Target stores may well also have been without AEDs at the time of Mary Ann's cardiac arrest.

Interestingly enough, the plaintiffs alleged that Target actually sold AEDs online at the time of Mary Ann's death. ${ }^{21}$ A reasonably good one, the plaintiffs claimed, could then be purchased from Target for less than $\$ 1200 .^{22}$ Presumably, Target's cost was considerably lower. Simply having the device is not enough of course. It has to be stored in a visible location, and apparently a typical case that both permits quick access but also discourages theft and vandalism costs $\$ 300-\$ 500 .^{23}$ And of course something must be spent to put the device in the case and attach it to a wall (or the like). Let us say the package amounts to $\$ 2000$, just to have a number in front of us. ${ }^{24}$ Assume there are 250 Target stores in California (which approximates the actual number). ${ }^{25}$ This means we are talking about initial costs of, say, \$500,000 to put one AED in every California Target store. Of course, if Target were to do this, it presumably would want as well to train people in the use of the AEDs, inspect and maintain its AEDs, and so on. This would take away time from other things that employees could be doing, although AED training could well be made part of other training the employees routinely receive. I do not know how to put a price on this but it seems safe to assume for these purposes that over, say, four years, this cost would be at least as much as the initial acquisition of the AEDs and their installation. So, for the moment, let us say, it would cost Target $\$ 1$ million over four years in California.

How many lives might be saved in that period with AEDs in all California Target stores? I have been unable to ascertain a reliable estimate of this, but here is some relevant information. The plaintiffs in their brief to the California Supreme Court cite the American Red Cross for the proposition that shopping malls are one of the more likely places for cardiac arrest to occur. ${ }^{26} \mathrm{~A} 1998$ article relied upon by Target in its brief identified just under ten cardiac arrests per year in more than 17,000 retail stores in the state of Washington, or one per 1,700 stores. ${ }^{27}$ This, of course, includes stores of all sizes. Given their much larger size and greater customer traffic one would expect a higher rate in Target stores. If, for this reason, the risk rate at Target stores was, say, three times higher — again just to have a

ORST tit $36 \S 431.690$ (2009).

Verdugo SC, supra note 1 at 794.

As of 11 September 2015 Target appears to have about 20 stores in Oregon.

The adoption date of SB556 which became ORST $\S 431.690$.

Verdugo 9th Cir, supra note 2 at 1052. According to Judge Pregerson's 9th Circuit opinion on remand, Target has since removed this product from their website but AEDs at a similar cost remain available from other online providers.

Verdugo, Plaintiffs' Complaint, supra note 1.

Verdugo SC, supra note 1 at 792.

Plaintiffs' brief to the California Supreme Court also uses this $\$ 2000$ number, see Verdugo SC, ibid (Brief of the Appellants) 2011 WL 2452556 at 4.

Verdugo SC, supra note 1, (Brief of Plaintiffs) 2013 WL 2367417 [Verdugo Plaintiffs' Brief]. Ibid at 9; Cardiact Arrest Survival Act of 2000, Pub L No 106-505, § 5, 114 Stat 2336 (codified as amended in 42 USC $\$ 238$ p (2003)).

Linda Becker et al, "Public Locations of Cardiac Arrest: Implications for Public Access Defibrillation" (1998) 97:21 Circulation 2106. To be clear, this article recommends placing AEDs in public places with the highest incidence of cardiac arrest and retail stores are not on the high incidence list - although no attempt was made to subdivide retail stores by size. 
number in front of us - then it would seem that one might expect one cardiac arrest per year per 500-600 stores, or something like two cardiac arrests over four years in all of Target's California stores.

A later article notes that the AHA guidelines call for providing an AED in public places where the risk of cardiac arrest is at least one every five years, and this article claims, based on Danish data, that this is a sensible guidepost from a cost/benefit perspective. ${ }^{28}$ On the numbers assumed above, the risk of a cardiac arrest at individual Target stores would appear to be considerably less than the AHA guideline. Moreover, not all of those having cardiac arrests would have their lives saved even if an AED were available (more on that below).

Taking all of these assumptions into account, suppose again for purposes of discussion that over four years Target stores in California would experience two cardiac arrests, and one life could have been saved in one of those stores if all had AEDs and trained personnel available. Getting Target to spend \$1 million over those four years in order to save one life is probably something that society would want Target to do. ${ }^{29}$ Indeed Target customers, if well informed, might well welcome the miniscule increase in the price of Target products that would happen were this cost passed on to them in order to get the protection of possibly having their own life saved in the unlikely event that they were the one. After all, on the numbers used so far the cost per Target store would be about $\$ 3$ a day over four years.

Of course, changing the numbers might quickly change how one feels about this. If only one life were going to be saved in 40 years, then spending say $\$ 10$ million to save it might be thought excessive; and besides, perhaps $\$ 10$ million importantly undercounts what Target's costs would be over 40 years. On the other hand, if Target's customer traffic made it, say, 15 times more likely to have a cardiac arrest occur in one of its stores as compared with the typical retail store — not just three times more likely as assumed above — then several lives may well be saved in four years. On that assumption, even assuming the labour costs of getting Target employees ready to use their AEDs are much higher than I have assumed here, an investment in AEDs might well be thought socially appropriate. ${ }^{30}$

I provide all this speculation about the potential costs and benefits of Target having had an AED in the Pico Rivera store where Mary Ann collapsed because this is exactly the sort of information that experts would testify about (and likely dispute about) if Mary Ann's case were to have gone to a jury to decide whether or not Target breached its duty of due care to her. ${ }^{31}$

Fredrik Folke et al, "Location of Cardiac Arrest in a City Center: Strategic Placement of Automated External Defibrillators in Public Locations" (2009) 120:6 Circulation 510.

29 Many US federal agencies put a value on a human life of well more than $\$ 5$ million when doing cost/benefit analyses of various regulatory proposals. For a discussion, see Memorandum from Polly Trottenberg, Under Secretary of Policy, US Department of Transportation \& Roberts Rivkin, General Counsel, to Secretarial Officers \& Modal Administrators [nd], online: <https://www.transport ation.gov/sites/dot.dev/files/docs/VSL\%20Guidance\%202013.pdf>.

30 In an op-ed calling on all big box stores to have AEDs, Arthur Hsieh argues: "These stores all have first aid kits, fire extinguishers, smoke alarms, emergency exits, sprinkler systems, and other safety equipment that costs far more and is used far less." See Arthur Hsieh, "Not Having AEDs in Big-Box Stores Puts Customers at Undue Risk," EMS1 (24 June 2014), online: <www.ems1.com/columnists/arthsieh/articles/1932765-Not-having-AEDs-in-big-box-stores-puts-customers-at-undue-risk/>. 
The jury could also learn about what the custom was among other "big box" store enterprises with respect to AEDs. It could well be that, like Target, the regular practice was not to have AEDs available in the stores; or, it might be that Lowe's had recently put them in their stores $^{32}$ but others did not; or, it might be that Wal-Mart, Costco, K-Mart, Home Depot, Best Buy, and Lowe's all had them, but Target did not. The role of "custom" is important in negligence cases; compliance with custom is typically good evidence of due care whereas non-compliance is typically good evidence of failure to exercise due care. ${ }^{33}$

But paying no attention to industry custom, the California Supreme Court concluded that Mary Ann's case should not go to a jury. It very explicitly made clear its view that it should not be the community, via the jury, that decides whether a reasonable big box enterprise like Target should have AEDs available to provide help to customers. ${ }^{34}$ Rather, the Court concluded, Target should not have to provide AEDs unless it is ordered to do so by the legislature - and as noted above, unlike Oregon, California has not imposed this obligation via a criminal statute on stores like Target.

What I find very misguided about the California Supreme Court decision is that it couched its decision in favour of Target on the ground that Target had "no duty" to have AEDs available in its stores. This is not what the "no duty" concept should be about.

"No duty" tort holdings should be reserved for situations in which the court concludes that it is legally permissible for someone to be negligent and nonetheless not be liable in tort for the harm they cause. Consider the "no duty" to rescue strangers doctrine mentioned above. Assume that D is sitting at the end of a pier reading her torts casebook in preparation for class the next day and she sees a stranger (X) fall into the water and cry out for help. Assume further that $\mathrm{D}$ could almost effortlessly toss a nearby life saving ring to $\mathrm{X}$ that would almost surely save X's life, but D does nothing and X drowns. In a wrongful death action against $\mathrm{D}$, even if a jury would have found that $\mathrm{D}$ behaved unreasonably (that is, negligently) in not tossing the life saving ring, D will not be liable to X's family. This is because under US tort law, as already noted, D owes $\mathrm{X}$ no duty of care..$^{35}$ That is, $\mathrm{D}$ is allowed to be negligent and escape liability.

Or consider a different California Supreme Court case. Assume (the actual facts of the case are somewhat changed to make the point more vividly) an armed robber comes into a fast food restaurant and points a gun at a customer in front of her and shouts to the cashier: "Give me the money in the register or I will shoot him!" The cashier says nothing, or says: "No. I am not allowed to do that." The robber says "I mean it" and shoots the customer in the leg, shouting: "Now give me the money or I will shoot him again." The cashier again says "No" and the robber shoots the customer in the head, killing or gravely wounding him. The robber then points the gun at the cashier and once more demands the money. By this AED was available to use on an employee who suffered a cardiac arrest while on the job and fellow employees had been trained to use it. See Lowe's Companies, Inc, "Training Saves a Life," online: Lowes Responsibility < responsibility.lowes.com/2014/stories/helping-after-sandy/>.

33 Third Restatement, supra note $5, \S 13$. Importantly, tort law permits juries to conclude that a business custom is insufficient - on the right evidence.

Verdugo SC, supra note 1 at 791.

Third Restatement, supra note $5, \S 37$. 
time others in the restaurant are crying out "Give her the money" and finally the cashier relents (perhaps only having been herself shot in the arm first). The robber then disappears with the money, and the customer who was shot (or his heirs) sues the fast food chain.

Based on the California Supreme Court decision in the KFC case ${ }^{36}$ the lawsuit will fail. Even if we assume a jury would have concluded that the reasonable thing to do in those circumstances was to have handed over the money, and certainly it is easy to imagine that a jury would decide that after the robber showed her seriousness with the first shot in the customer's leg, the fast food chain would win. The reason is that the Court concluded that stores in this situation have "no duty" to exercise due care in the individual case.

Although I am troubled by the decision, I concede that the argument the Court gave to justify its decision was an appropriate "no duty" argument. It decided that if there were a legal duty to comply with these demands, it would invite a large increase in armed robbery attempts and that in turn is likely to result in even more deaths than if stores refuse to cooperate with such demands. ${ }^{37}$ This is an empirical prediction about which I have real doubts, but it is not a preposterous one. Indeed, the same prediction is what causes some countries to refuse to cooperate with terrorist demands and/or to prevent family members from cooperating with the ransom demands of kidnappers. Looking at the matter at what I call the "retail level" — from the individual event — the sensible solution is to pay the money to save the life. But if this generates a rash of such incidents, then from the overall society perspective - what I call the "wholesale level" — it is perhaps, alas, the better solution to sacrifice the immediately-threatened victim for the greater long-term social good. Of course, juries might think about this wider trade-off if asked to decide whether the fast food cashier was reasonable in refusing to hand over the money to save the customer from being shot; but with their focus on the facts of this case (the "retail level"), they are likely to ignore the wider long-term matter (the "wholesale" level). So, if one truly believes that imposing tort liability will in the end do more overall harm than good, then one can see why a court might elect to treat this as a "no duty" case and keep the matter from the jury.

The California Supreme Court has done the same thing with respect to certain recreational injuries. ${ }^{38}$ When there is an injury to one participant by another (say, one skier runs into another), it turns out that it is all right to be negligent — at least as a legal matter. So, for example, if you are skiing sensibly and are unexpectedly struck from behind by a clearly careless snowboarder, you have no valid tort claim against your injurer. The reason for this, says our Court, is that otherwise ordinary Californians would be afraid to engage in recreational activity for fear of being sued. (Cal 1997).

37 Ibid at 1270. The Court also emphasizes the right of property owners to defend their property with reasonable force (ibid at 1269-70). This additional argument that since it is the store's money at stake it should never have to give it up seems preposterous to me, since we are always making stores spend their money to comply with the ordinary duties of due care. 
The Court's thinking seems to go like this: when people engage in recreational activities accidental harms frequently occur that are not caused by negligence. If the regular rules of tort law applied, would-be participants would worry that they might not be properly exonerated by the jury even if they had actually been careful; and because of that fear, droves of Californians will stay at home and watch TV. So, to prevent the worse overall social outcome - a predicted drastic reduction in recreational activity in the state - it is now legally all right to engage in these activities in a careless way. Once again I have real doubts that the Court's empirical prediction - the negative social consequences the Court fears would actually occur were routine negligence law applied to such lawsuits. ${ }^{39}$ But that is not the point here. The point is that this case also illustrates an appropriate use of the "no duty" doctrine. Under that doctrine it is permissible to be careless and not be held liable in tort in certain circumstances - and a worse overall social outcome if tort recovery were allowed is one of those circumstances.

But this is not what Mary Ann Verdugo's case is about. The Court is not claiming that big box stores like Target and all the great things they arguably do for California consumers will disappear unless they are allowed to be negligent with respect to helping out customers who have heart attacks on their premises, or that ill people will rush into Target stores seeking medical care if Mary Ann's family were to win their case, or that any other negative overall social outcome would occur. Nor are the justices arguing that there will be a flood of cases that will overwhelm the courts if this sort of lawsuit is allowed, or that there are other appropriate places for Mary Ann's family to obtain compensation, or any of the other reasons that are appropriately given in certain settings for why tort law allows those who fail to use due care to escape liability. ${ }^{40}$

No, what is really going on here is that the California Supreme Court is not convinced that Target was at fault. It acknowledges that there is of course some foreseeable chance that someone will have a heart attack in a Target store who could be saved by having an AED around. But it properly points out that the chance seems very small. Moreover, unlike health clubs, the chance does not seem particularly higher than average in a Target store although the more people in the store presumably the greater the chance of someone having a sudden cardiac arrest. $^{41}$

The Court's next move then is to assert that the precaution that Mary Ann's family claims Target should have taken is more than minimal (as compared with the burden of calling 911, which the Court sees as minimal). ${ }^{42}$ Putting those two together, the justices do not see the case having been made for requiring Target to do more - that is to have the AED. To me,

If nothing else, that does not seem to have occurred in states like Wisconsin, for example, that apply ordinary negligence law to such accidents; that is, by imposing a general duty of due care on recreational activity participants. See Lestina $v$ West Bend Mutual Insurance Co, 501 NW (2d) 28 (Wis 1993).

40 For a discussion of the many arguments that can justify a true "no duty" decision, see Sugarman, supra note 3 .

41 Moreover, given the enormous size of these big-box stores it may be difficult for emergency medica technicians to actually find a customer who collapsed in the aisle as the plaintiffs claimed was true in Mary Ann's case. See Verdugo Plaintiffs' Complaint, supra note 1; Verdugo Plaintiffs' Brief, supra note 25 .

42
Verdugo SC, supra note 1 at 791. 
this is simply deciding that there was "no breach" of Target's duty of due care towards Mary Ann. ${ }^{43}$ In the end, that might be the right result in this case.

But in US tort law, whether or not there has been a "breach" is normally a question for the jury, not the trial judge or higher level courts. While deciding that there is "no duty" to be careful is a question of law for the court, as I have emphasized here, that is not how this case is really being decided. And to call it a "no duty" decision is to obscure the fact that what is normally a jury question is being decided.

This is not to say that judges should never decide the "breach" issue. When the facts claimed (or reasonably proved) are such that no jury could reasonably find for the plaintiff, then the trial judge should rule in favor of the defendant as a matter of law (when asked to do so) and the failure to so rule is ground for reversal on appeal. ${ }^{44}$ And perhaps the opinion in Mary Ann's case could be rewritten to yield this result - that is, the plaintiff has not offered to prove any set of facts on which a jury could find that Target should reasonably have had an AED available at this store (and at least one employee there to step up and deploy it). But that is not how the opinion is cast, and that sort of position is inconsistent with what is alleged in the plaintiffs' pleading. ${ }^{45}$

After all, the plaintiffs had sought to show why a reasonable store like Target should indeed have had an AED available, and normally we allow plaintiffs to go ahead with their case to see what evidence they can muster (only ruling for the defendant as a matter of law after the evidence presented by the plaintiff, even if viewed most favourably to the plaintiff, just does not make out a plausible case of inadequate precaution). That did not, and will not, happen here. This seems wrong.

Precautions are what the "breach" issue is all about, and what we ask juries to decide is whether the precaution that the plaintiff said the defendant failed to take was one that a reasonable person under the circumstances should have taken. ${ }^{46}$ This is the meat and potatoes of jury decision-making.

It is critical to appreciate that this is exactly what the California Supreme Court conceded it was unhappy about: allowing juries to decide. The Court was concerned about jury inconsistency and about how it could be determined just when a store was large enough that an AED should be provided, and when it was not. ${ }^{47}$ So, it took the matter away from the jury, declaring that if AEDs are to be required more widely than they are now, this should not be done via the common law but by the legislature. After all, if it thought it was a good idea, the legislature could copy Oregon, and so far in California the legislature has made the deliberate decision to only require AEDs of certain businesses like fitness centers.

See Third Restatement, supra note 5, $\S 40$, $\mathrm{cmt} \mathrm{d}$ (which is the right way to deal with this matter). Ibid.

Verdugo Plaintiffs' Complaint, supra note 1. Note that the federal district court in this case initially held that California's statutory scheme concerning AEDs "occupied the field" and since AEDs were required in some places but not Target, common law liability was pre-empted. The California Supreme Court very thoughtfully rejected this argument (ibid at 781-88).

See Mark F Grady, "Untaken Precautions" (1989) 18:1 J Leg Stud 139 on how the pleadings shape the case by identifying the precaution that the plaintiff alleges a reasonable actor would have taken. Verdugo SC, supra note 1 at 791-93. 
But this line of argument is altogether incompatible with the traditional role of juries. If a victim of a car crash claims that the defendant auto company should have had some safety device or a different safety design, this question is normally for the jury - even if very technical. We do not say that just because this specific safety device is not currently mandated there is "no duty" to have it. Or, if a customer is attacked in a motel room and claims that a proper lock on the door or window would have prevented the attack and the motel should have had such a lock, we do not say that it is up to the legislature to decide; and if such locks are not currently required by statute there is "no duty" to have one. We leave this to the jury to decide. Yes, juries can reach inconsistent results in similar cases. Yes, juries may not be at all expert on technical matters. But in the US this is the system we have.

The California Supreme Court cites the Ann M. case, an earlier decision of the Court, which contains the same misuse of the "no duty" idea. ${ }^{48}$ There, the plaintiff claimed that a security guard should have been provided at the premises, and had one been provided she would not have been raped. The Court concluded that there was "no duty" to have a security guard on the facts as pleaded. The central reason for this result, however, was the same reason asserted in Mary Ann's case - that it would be too burdensome on business. This matter of the burden of precaution goes, however, not to "duty" but to "breach." 49 It is all right with me for the Court to conclude that as a matter of law on the facts of Ann M, no jury could reasonably find that a reasonable property owner would have provided a security guard. But that is a holding about breach, not about duty.

The California Supreme Court might be rejecting section 40 of the Third Restatement. Oddly, it refers repeatedly to section 314A of the Second Restatement, ${ }^{50}$ the precursor to the new section 40. Section 314A says this about a business entity like Target that holds its stores open to the public: it is "under a duty" to its customers "to take reasonable action ... to give them first aid after it knows or has reason to know that they are ill or injured, and to care for them until they can be cared for by others." If section 314A is the law, then the plaintiffs in Mary Ann's case are, in effect, arguing that in today's world having an AED available is part of the reasonably required "first aid."

One could engage in some hair-splitting grammatical analysis, claiming that since the AED would have to have been in the store before Mary Ann had her cardiac arrest, this is outside the provision of section 314A since "first aid" contemplates acts taken after an employee realizes that someone is ill. I find this quite unpersuasive since even calling 911 after someone collapses on the store floor also requires acting in advance by training employees that 911 is the number to call, and acting in advance is required in order to have a first aid kit in the store so that bandages can be applied to customers who are bleeding.

In any event, section 40 of the new Third Restatement does not refer to "first aid' but instead speaks generally of "reasonable care." ${ }^{51}$ Tellingly, comment $\mathrm{d}$ to the new section 40 speaks directly to this change in phrasing, noting that while section 314A focuses on "first 
aid," "[t]his Section adopts a more general duty of reasonable care, thereby recognizing both the variety of situations in which the duty may arise and advancements in medical technology that may enable an actor to provide more than just first aid." 52 To me, the potential (although not necessary) application to AEDs could not be clearer. ${ }^{53}$

Of course, the California Supreme Court could elect to reject section 40 and explicitly conclude that in California Target is allowed to take less than the reasonable care that the Third Restatement now imposes. But as the Court seemed oddly locked into the prior Restatement, it was not squarely confronted with this tension - perhaps because both briefs cite only to section $314 \mathrm{~A} .{ }^{54}$ This is rather weird in itself. Section 40 of the Third Restatement was contained in Tentative Draft No. 4 which was approved by the American Law Institute (ALI) membership in 2004; the larger portion of the Third Restatement in which section 40 appears was again approved in 2010, and the ALI published section 40 as superseding the old section 314A in 2012. ${ }^{55}$ The briefs were filed in April and August of 2013, and Mary Ann's case was decided in June 2014. Why the Supreme Court justices and their clerks remained seemingly unaware of this development is obscure.

A different way to think about the decision in Mary Ann's case is in terms of the debate in tort law about the comparative benefits and costs of "rules" versus "standards." For torts purposes, the "due care" principle is seen as a "standard." Saying that Target employees must call 911 but that Target need not supply an AED could be deemed a "rule" about what is "due care."

Apart from the problems with adopting such a "rule" in this situation (discussed next), the most important thing to notice is that "rules" versus "standards" debate concerns "breach" not "duty." Of course, it fits the non-professional use of the English language to say that if a rule calls for doing $\mathrm{X}$ but not $\mathrm{Y}$ and the defendant did $\mathrm{X}$ then the defendant has "no duty" to do Y. But this too quick deployment of the "no duty" phrase conflates the two distinct ideas of tort doctrine. Had the Court meant to go down the "rule" line, it would be much better to have said that since it was adopting "call 911 only" as the "rule" for determining whether there was a breach of the store's duty of reasonable care in these settings, then Target is not liable for failing to have had an AED because it exercised due care by calling 911.

Whether the Court should adopt such a "rule" is another matter. The big advantages of "rules" are: (1) consistent treatment of similar cases; (2) would-be defendants can clearly know what is expected of them; and (3) cases can be resolved more quickly and easily, as

$52 \quad$ Ibid, cmt d.

Indeed the Reporters' Note to Third Restatement, ibid, $\S 40$, cmt d, mentions the federal requirement of having AEDs on airplanes and a federal district court decision sympathetic to this requirement (Stone $v$ Frontier Airlines, Inc, 256 F Supp (2d) 28 (Mass Dist Ct 2002)), while acknowledging that in Salte $v$ YMCA of Metropolitan Chicago Foundation, 814 NE (2d) 610 (Ill App Ct 2004) the defendant was found not to have breached its duty of care to its health club patrons by failing to have an AED on the premises.

$54 \quad$ Verdugo Plaintiffs' Brief, supra note 25; Verdugo SC, supra note 1 (Brief of the Defendant) [Verdugo Defendant's Brief] [on file with the author].

55 Email to the author on 2 October 2015 from Professor Michael D Green, co-Reporter for this portion of the Third Restatement, supra note 5. 
either many claims will not be brought or when they are then liability will often be clear. ${ }^{56}$ Yet, there are definite costs to "rules": (1) technology may change suggesting that what was once sufficient is no longer so; (2) facts vary enormously from case to case, and while a certain rule might seem to have made sense in the case where it was adopted, in a new case it may seem quite wrong; and (3) social norms may change such that, for example, society may become more risk-averse and more eager than before to have certain precautions taken that were not thought appropriate in the past. Leaving it to juries to apply the reasonable care "standard" allows for all of these adjustments. To me that argues for rejecting a "rules" approach here. By contrast, the opinion in Mary Ann's case reflects a basic distrust of juries. ${ }^{57}$ This is probably alarming to US tort lawyers because our longstanding system, as noted already, is based on jury trials in personal injury and death cases. In any event, for my purposes here the central point is that the Court did not cast its opinion as one that was establishing a "rule" as to what constitutes reasonable conduct in this setting.

Furthermore, I should make clear that my concern applies even if there were no jury requested in this case, as well as in common law jurisdictions where juries are not used in these sorts of civil cases. It is still important as a doctrinal matter how a judge disposes of the case. A trial judge can conclude "I find the precaution proposed too burdensome and so there was no breach of the defendant's duty to take due care." That is fine. Or a higher court can conclude "We decide that the rule for measuring breach in this class of cases is X and since the defendant clearly complied with the precaution required by $\mathrm{X}$, we find the defendant not negligent as a matter of law." That too is fine. But it is very different to say, "Even though I or we may well agree with the plaintiff that defendant failed to exercise due care here, the defendant wins because she owes the plaintiff no duty of care." That latter statement should be reserved for cases in which some overriding policy reason makes it necessary to allow careless defendants to escape tort liability. ${ }^{58}$

It is important to appreciate that making this a question of breach does not mean that plaintiffs such as those who brought Mary Ann's case will necessarily win. After all, upon hearing the evidence the fact finder might conclude that the burden on Target of having an AED and people who know how to use it is indeed too great given the limited benefit it might achieve.

In addition, there is the further question of whether having an AED in this Target store would in fact have saved May Ann's life - since the plaintiffs in this case would have had to prove not only a breach of the due care standard but also a causal link between that breach and Mary Ann's death. ${ }^{59}$ This "causation" question is itself a very difficult and problematic one here. In their brief to the California Supreme Court the plaintiffs claimed a 50 to 70 percent success rate when AEDs are used but they may not have been able to prove that was

\footnotetext{
56 See Oliver Wendell Holmes Jr, The Common Law (Boston: Little Brown, 1949) at 123-24; Holmes' famous decision in Baltimore \& OR Co v Goodman, $10 \mathrm{~F}$ (2d) 58 (6th Cir 1926).

For Cardozo's classic response, see his opinion in Pokora v Wabash Railway Co, 292 US 98 (1934).

Restatement (Third) of Torts, supra note $5, \S 40, \mathrm{cmt} b$, referring as well to $\S 7, \mathrm{cmt} \mathrm{b}$ (the Restatement's general provision concerning "no duty").

This is a typical issue in many sorts of negligence cases. The defendant has breached its duty of due care, because if it had taken the precaution identified many people would have benefitted but not everyone. As a result any particular plaintiff may not have benefitted, and so in order to win she must prove "causation" by demonstrating that it is more likely than not that she would have.
} 
Mary Ann's lost chance. ${ }^{60}$ Target countered that the success rate of having AEDs was less than 50 percent and therefore it is more likely than not that she would have died even if Target had made an AED available. ${ }^{61}$ As Target's lawyers pointed out, the large size of a Target store means that some sales associate would have to identify that a customer is in real need and summon the person in the store trained to find and use the AED; all of this would take time and AEDs can save lives only if they are applied very quickly. Moreover, given that in many cardiac arrests AEDs are of no help anyway even if immediately applied, the likelihood that any specific customer would have her life saved is highly speculative and, in Target's reading of the literature, clearly less than 50 percent. ${ }^{62}$ Is there a special reason to think that Mary Ann would be more likely to have been saved than the average person having a cardiac arrest? Perhaps her age would count in her favour on this, or maybe not. ${ }^{63}$ Anyway, this "causation" issue too would probably be battled out by experts at the trial stage were the matter to have been allowed to proceed and not tossed out on "no duty" grounds.

\section{Mary Ann's case is hardly the only recent decision to misuse the "no duty" doctrine.}

\section{BELIZAIRE V. FURR}

\section{A 15 September 2015 decision of the Massachusetts Appeals Court notes that:}

As a general rule, a landowner does not owe a duty to take affirmative steps to protect against dangerous or unlawful acts of third persons. Luoni v. Berube. The Supreme Judicial Court has, however, explained that in certain exceptional circumstances, "[1] andlords may be liable for ignoring criminal activities that occur on [their] premises and were known or should have been known to them." Griffiths v. Campbell. ${ }^{64}$

In the case before Belizaire, a guest at a party held in the defendant's apartment was killed by an unknown assailant, and a wrongful death claim was brought against the owner for negligently failing to keep the apartment safe. At the end of the trial the trial judge granted a summary judgment for the defendant and the plaintiff appealed.

Verdugo Plaintiffs' Brief, supra note 25. This is based on a statement in the dissenting opinion out of the 9th Circuit, which refers to hearings before the California legislature. See US, SB 1436, An act to amend and repeal Section 1797.196 of the Health and Safety Code, relating to automated external defibrillators, 2011-12, Reg Sess, Cal, 2012. Note that this strong chance of success was coupled with two further assumptions: (1) the use of CPR as well; and (2) application of CPR and AED within 3-5 minutes of the sudden cardiac arrest. A 60 percent survival rate when AEDs are used within 3-4 minutes is claimed in an OSHA guide (2006) urging employers to have an AED at the worksite. See Verdugo Plaintiffs' Brief, ibid.

61 Had the absence of an AED deprived the plaintiff of, say, a 30 percent chance of survival, one might imagine the lawyers arguing for recovery on the "loss of a chance theory," but for now that sort of cause of action seems confined to medical malpractice cases. See generally Matsuyama v Birnbaum, $890 \mathrm{NE}$ (2d) 819 (Mass 2008).

62 Verdugo Defendant's Brief, supra note 54. See American Heart Association, "Every Second Counts: Rural Community Access to Emergency Devices" (March 2013), online: American Heart Association <www.heart.org/idc/groups/heart-public/@wcm/@adv/documents/downloadable/ucm_301646.pdf> (this document suggests a 40 percent success rate). Although that number is a bit confusing since elsewhere in the fact sheet it claims that about a quarter of those who suffer cardiac arrests are candidates for AED treatment.

63 The plaintiffs' initial pleading reveals that Mary Ann had "developmental disabilities and mental and verbal limitations leaving her incapable of asking for help and protection.” Verdugo Plaintiffs' Brief, supra note 25 . Whether her health conditions might have been relevant to her potential survival rate had an AED been available at Target could have been addressed at trial. 
The Massachusetts Appeals Court concluded that no evidence was presented on which it could be said that there was any foreseeable risk of criminal harm to those at the party. On this basis the summary judgment was properly granted, the Court concluded. This seems fine.

The problem I have is with this statement the Court then made: "Thus, the required elements, including a duty of care owed to the victim, have not been established here." ${ }^{65}$ This is the wrong way to put it.

I believe that the host in this instance does, or at least should, owe a duty of due care to social guests. But because there was no foreseeable risk of this sort of harm to the guests in this case, one can fairly conclude that there was no breach of the duty of due care and hence a judgment for the defendant should follow as a matter of law. The Third Restatement supports this way of analyzing this case: foreseeability goes to "breach" not "duty."

Others might argue that hosts should not owe any duty at all to guests to take reasonable care of them if they are in need of help while in the host's home. Section 40 of the Third Restatement does not include social hosts and guests in the list of those relationships that give rise to a duty of affirmative assistance. Social hosts are not commercial actors (like Target) and the Third Restatement treats them and their guests like strangers (like the person who is in the water and needing an easy rescue from the stranger at the end of the pier). ${ }^{67} \mathrm{I}$ do not like this result, but I would accept the "no duty" holding if, in the Belizaire case, it were put in terms of an insufficient (or the wrong type of) relationship. But that is not what the court did. What was wrong was to say that there is "no duty" on foreseeability grounds.

Suppose instead the guest had collapsed (as in Mary Ann's case) and been clearly in need of aid but the host did not even bother to call 911 for help. A "no duty" position would relieve the host of liability even when the need for care was self-evident and a jury would have found the host to have behaved unreasonably if given the opportunity to so find. By contrast, if a duty of due care does arise from this relationship then surely it would have been breached in this latter example. ${ }^{68}$

66 Third Restatement, supra note $5, \S 7$, cmt j. See also ibid, $\S 37$, cmt f (where the point is reiterated).

67 The Third Restatement, ibid, leaves open the possibility that courts will extend the duty to come to the aid of someone in need to people in other relationships. See ibid, $\$ 40$, cmt o.

68 The New York legislature recently adopted an Assembly Bill that would have imposed a tort duty of due care on hosts to look after guests in their home who are in need of emergency care, US, AB 3303B, An Act to Amend the General Obligations Law, 2013-14, Reg Sess, NY, online: <www.nysenate.gov/ legislation/bills/2013/A3303B>. Called the "Steven Kovacs Law" this bill was adopted in response to a situation in which hosts allegedly ignored a very ill guest who then died. But this law was then vetoed by Governor Cuomo. For background on the law and commentary in support of the Governor's veto, see Oscar Michelen, "NY Gov Vetoes Bill Imposing Liability on Homeowners for Inaction," (30 December 2014), Courtroom Strategy (blog), online: <www.courtroomstrategy.com/2014/12/ny-govvetoes-bill-imposing-liability-on-homeowners-for-inaction/ $>$. 
Notice that the Third Restatement does not impose a duty on a host to come to the aid of an ill guest under the rules governing land possessor liability because that duty is imposed with respect to conditions of the property. ${ }^{69}$ In Belizaire the plaintiff seemed perhaps to be trying to characterize the circumstances of the attack on the victim while at the defendant's party as arising out of the property's condition, but this seems not to be what the Third Restatement had in mind in its provisions about land possessor duties.

In any event, this mistaken way of putting things in cases of landowners failing to prevent criminal acts on their property is, alas, a familiar one as can be seen, for example, in a case involving an attack on a customer in the parking lot of a Wal-Mart-owned store. ${ }^{70}$ There, section 40 of the Third Restatement clearly requires Wal-Mart to take reasonable precautions to protect its customers from such attacks. ${ }^{71}$ In this case, however, many of the precautions that other commercial property owners unreasonably had failed to take in prior lawsuits were not in play. This store was only open during daylight hours, and since it was daylight when the mugging occurred a failure to have lights was irrelevant. So, too, as the parking lot had no trees or shrubs in it, more careful pruning to preclude places for muggers to hide was a nonstarter. Wal-Mart did not have visible cameras in the lot that plausibly could have deterred people from robbing customers there, but the plaintiff did not argue that this failure was a breach of the care owed to her. I suspect this was because her lawyer concluded that such cameras would probably have made no difference in her case (the mugger somehow hid under her car and when she returned to it from the store, the robber grabbed her ankle, pointed a gun, and demanded that she hand over her jewelry and her wallet). Instead, the claim in this case was that Wal-Mart was negligent in failing to have a security guard in the parking lot.

The plaintiff's evidence in the case indicated that in the past six plus years there had been one other prior personal attack on a customer by a stranger in the parking lot. In each of a dozen or so other nearby stores it appears that there had been an average of perhaps one such predatory attack on people per store per year (seemingly making the Wal-Mart store and its premises considerably less dangerous, at least in the past). The nearby residential neighbourhood was understood to be a somewhat dangerous place. The trial judge (in a bench trial held without a jury) concluded that Wal-Mart had failed to exercise due care by not having a security guard in the parking lot (seemingly relying at least in part on the fact that it had a security guard inside the store at the time of the mugging who was presumably there to protect the store's cash). The judge awarded the victim about $\$ 30,000$, including $\$ 10,000$ for her pain and suffering. ${ }^{72}$

The Louisiana Supreme Court reversed. I would have had no objection had the trial judge in this case concluded that the cost of a security guard was an unreasonable expense to expect Wal-Mart to incur given the low risk of such crimes on its property, thereby finding

Third Restatement, supra note $5, \S 51$.

Posecai v Wal-Mart Stores, Inc, 752 So (2d) 762 (La 1999) [Posecai].

For a discussion of the criminal attack cases, see the Reporters' Note to Third Restatement, supra note $5, \S \S 40,51$.

72 There is every reason to assume that the plaintiff's lawyer would have taken at least all of the pain and suffering award as a legal fee. There is no indication (nor would there be) as to whether the victim was insured; if she had been, this would actually have been a battle between her property insurer and WalMart (and its liability insurer unless Wal-Mart self-insures). 
that Wal-Mart had not failed to exercise due care. But of course, the judge found otherwise. I would have had only a minor objection had the Louisiana Supreme Court held that the trial judge was wrong in finding that Wal-Mart breached its duty of due care towards the plaintiff and either sent the case back for a re-trial or even reversed the trial court decision as a matter of law and ordered the judge to enter a verdict for the defendant on the grounds that there was insufficient evidence on which it could be found that Wal-Mart failed to take a reasonable precaution.

But what I object to is the Court's conclusion that Wal-Mart had "no duty to protect Mrs. Posecai from the criminal acts of third parties under the facts and circumstances of this case." 73 To me the Court's opinion is clearly all about "breach." Indeed, it openly adopts a "balancing" test in analyzing the case before it, considering both the risk of criminal attacks on customers and the burden on businesses of preventing such attacks. ${ }^{74}$ This, of course, is exactly what juries (or judges in bench trials) are supposed to do in deciding whether the defendant has breached its duty of due care. Here the court rested its decision centrally on the low probability of such an attack - a matter of foreseeability. But this, to repeat, should be viewed as going to the matter of whether or not there has been a breach of the duty of due care.

In short, just as in the California AED case against Target and the Massachusetts case of the attack on a guest at a party, this parking lot mugging case shows yet another appellate court converting a low risk of harm case into a "no duty" decision. This is misleading. Moreover, it is not only in low foreseeability cases where the "duty" concept is being misused as the next recent example illustrates.

\section{EDWARD C. V. CITY OF ALBUQUERQUE}

Four year old Emilio C. was sitting with his family at a Little League party in a picnic area of the defendant's minor league baseball park. The picnic was taking place before the game started. Emilio was struck in the head and suffered a fractured skull when he was hit by a ball belted beyond the left field wall and into the picnic area during before-the-game batting practice. At the time of the accident he and his family allege they had no reason to notice that batting practice had started and that there was a risk of a ball coming their way.

The trial court granted the defendants a summary judgment based on the "baseball rule." The Court of Appeal reversed, rejecting the "baseball rule" and concluding that the plaintiffs were entitled to a jury decision as to whether or not the defendants breached their general duty of due care towards Emilio. ${ }^{75}$ In a 2010 decision, the New Mexico Supreme Court roughly split the difference, adopting a "limited-duty baseball rule" and sent the case back for further proceedings on the ground that under its statement of the law summary judgment should not have been granted. ${ }^{76}$ This is the wrong use of "limited duty." 
What has become known as the "baseball rule" is that a ballpark satisfies its duty of due care to customers if it provides a screened area of seats sufficiently large to satisfy customer demand. In practice this means that so long as there is a screen behind home plate that protects fans sitting behind the screen from being hit by foul balls or bats, the ball park has taken reasonable care. So understood, the "baseball rule" is a "rule" about what precautions ballparks should reasonably take.

Many would agree that this rule works reasonably well when it comes to foul balls or broken bats that fly towards the crowd during a game. After all, flying balls and bats are most dangerous right behind home plate, and fans sitting there are often closest to the field and at greatest risk of being hit because they were unable to get out of the way (or catch the ball themselves). At the same time, many fans come to games wanting an unobstructed view, and many of those also are eager to catch or otherwise retrieve a foul ball if they can to be taken home as a souvenir. That is to say, customers overall do not want all the seats to be screened. Anyone not wanting to sit behind the screen (or who finds those seats too expensive) can almost always find loads of seats that are both out of the range of any flying broken bats and actually or virtually always out of the range of hit balls.

Still, many fans are struck by balls each year and some are hit by bats (usually broken bats). But the "baseball rule" takes the position that to prevent those injuries would require precautions that we do not actually want ball parks to take. Like "rules" in general, under the "baseball rule" stadium operators are clear on precisely what they have to do to avoid liability for these inherent risks of the game. But, this should not be termed a "limited duty" rule; rather it is a "rule" about what is or is not a "breach" of the due care standard.

A shortcoming of the "baseball rule" for during-game ball and bat injuries is that some ball parks might have much smaller screened-in areas, leaving those just outside the screen far more vulnerable to serious injury than are fans at most stadiums; a related shortcoming is that some ball parks might have unscreened seats that are far closer to the field than at the typical park, once more putting some fans at a much higher risk than normal. As with the "rules" versus "standards" debate discussed above, this problem could be handled by just applying the normal "reasonable care" standard to ball parks, taking each case up on its own and giving ballparks strong protection on a case-by-case basis if their protected seating area conforms to industry custom. But I put that aside.

The point here is that even if the "baseball rule" as applied to balls and bats that hit fans during the game makes sense in that setting, it makes no sense here where a child was struck by a ball hit into a picnic area before the game began. This situation is not one in which fans are eagerly awaiting hit balls to take home as souvenirs; nor it is a situation in which fans are eager to be watching the game unobstructed by a net.

Remember that the people in the ballpark are paying customers to whom a duty of due care is owed. There is no overriding reason to allow baseball park owners to be negligent towards fans and escape liability on a "no duty" basis. And that is why suits have clear promise when an employee vendor carelessly drops a heavy object on a fan or when an employee mascot carelessly tosses dangerous objects out into the stands during breaks in the game. 
Here the family could not even see the batter's box and, according to the complaint, they had no idea that batting practice had even started let alone that a hard hit ball might reach where they were. The minimum precaution they say should have been taken was a warning; alternatively maybe it was a breach of the ball park's duty not to have fan picnics and batting practice happen at the same time unless a screen were put up over where they were sitting. In any event, they quite convincingly argue that whether or not this ballpark operator was at fault in these circumstances should be judged by the ordinary due care criteria. It is not and should not be a matter of duty or limited duty at all.

In the end the New Mexico Supreme Court gets to this result. But it gets there with the wrong language. It concludes that "[s]pectators must exercise ordinary care to protect themselves from the inherent risk of being hit by a projectile that leaves the field of play and the owner/occupant must exercise ordinary care not to increase that inherent risk." it is adopting a "limited duty" rule in which the ball park operators have a duty that is "symmetrical" to the spectators.

First of all, when it comes to fans hit by balls in the course of a game, a strict application of this statement would allow teams to provide no screened seats at all since they are not increasing the inherent risk of the game by having unscreened seats right behind home plate where fans could be seriously injured all the time. That surely is wrong and would give ball park operators even less of a burden of precaution than is required by the "baseball rule." The Court in fact seems just to have misspoken here because elsewhere in the opinion it clearly rejects the "baseball rule" as too stringent. ${ }^{78}$

What the Court means to say is that it is fine with the "baseball rule" as a general matter for during-the-game foul balls and flying bats. But it rejects that rule for injuries to fans that do not arise out of an inherent part of the game. For those, the ordinary due care principle is to apply. Hence, the case should go back to the trial court to explore whether due care was provided with respect to Emilio and his family. I do not have a strong objection to this result, but I do to characterizing New Mexico law going forward as embodying a "limited duty" of ball parks based on a "symmetrical" relationship with customers. The opinion is all about what trial courts should look to in deciding whether the ball park was careless when a fan is injured. That is, it is all about "breach." And having the "baseball rule" apply to some injuries and the ordinary due care standard apply to others is an acceptable way of resolving the breach issue. This is not about creating certain settings in which the court is saying that is all right for the ball park to be unreasonably careless (that is, demanding a less-thannormal duty of care).

\section{CONCLUSION}

There are some defendants who have no legal duty to act reasonably, and so when they fail to exercise what normally would be due care under the circumstances and this failure causes harm, they are not liable to their victim(s) in tort. Just when "no duty" is owed is a matter for judges to decide. But "no duty" is not about determining the appropriate 
precautions that reasonably prudent actors should take, nor is it about the degree to which an actor's conduct (or failure to act) foreseeably risks harm to another. These considerations - the risks taken and the burden to prevent them - go to whether an actor with a duty of care towards another has "breached" that duty. Too many US appellate courts are misapplying the "no duty" doctrine in situations in which they are actually deciding there has been "no breach." It would be clearer and better, and courts would be forced to be more candid and reflective about the relative roles of judge and juries, if courts followed the guidance of the Third Restatement. ${ }^{79}$ 
This page is blank - do not strip it in 